\title{
HEPTADIC VERBAL PATTERNS IN THE SOLOMON NARRATIVE OF 1 KINGS 1-11
}

\author{
John A. Davies
}

\begin{abstract}
Summary
The narrative in 1 Kings 1-11 makes use of the literary device of sevenfold lists of items and sevenfold recurrences of Hebrew words and phrases. These heptadic patterns may contribute to the cohesion and sense of completeness of both the constituent pericopes and the narrative as a whole, enhancing the readerly experience. They may also serve to reinforce the creational symbolism of the Solomon narrative and in particular that of the description of the temple and its dedication.
\end{abstract}

\section{Introduction}

One of the features of Hebrew narrative that deserves closer attention is the use (consciously or subconsciously) of numeric patterning at various levels. In narratives, there is, for example, frequently a threefold sequence, the so-called 'Rule of Three'1 (Samuel's three divine calls: 1 Samuel 3:8; three pourings of water into Elijah's altar trench: 1 Kings 18:34; three successive companies of troops sent to Elijah: 2 Kings 1:13), or tens (ten divine speech acts in Genesis 1; ten generations from Adam to Noah, and from Noah to Abram; ten toledot ['family accounts'] in Genesis). One of the numbers long recognised as holding a particular fascination for the biblical writers (and in this they were not alone in the ancient world) is the number seven. Seven

1 Vladimir Propp, Morphology of the Folktale (rev. edn; Austin: University of Texas Press, 1968; tr. from Russian, 1928): 74; Christopher Booker, The Seven Basic Plots of Literature: Why We Tell Stories (London: Continuum, 2004): 229-35; Richard D. Patterson, 'The Use of Three in the Bible', http://bible.org/seriespage/use-three-bible (accessed 7 October 2011); Michael Russell, 'On the Third Day, According to the Scriptures', Reformed Theological Review 67 (2008): 1-17. 
conveys the idea of completeness in biblical and Semitic texts generally. ${ }^{2}$ Thus some narrative events, particularly at key turning points, are repeated seven times: Joshua marching around Jericho (Joshua 6:15); Elijah's servant looking toward the sea as the drought is about to break (1 Kings 18:43); Naaman bathing in the Jordan before being healed (2 Kings 5:10). According to Markova, Njoh, and Lloyd there is a higher incidence in the Pentateuch of the numeral seven, or numbers beginning with seven, than would be expected according to Benford's law (lower numerals naturally occur with higher frequency than higher numerals in a descending logarithmic scale). ${ }^{3}$ Heptadic units are also used as a structuring device in the Hebrew Bible at the macro and micro level, often in a chiastic arrangement, as developed, for example, by Dorsey (even if not all of his structural analyses are accepted). ${ }^{4}$ Most famously, of course, we have the literary framework of the seven-day creation week of Genesis 1 (strictly 1:1-2:3). We also find aggregations of seven closely related items, e.g. the catalogue of Abram's possessions in Egypt (Gen. 12:16), the list of those who are to rest on the Sabbath (Exod. 20:10), the 'seven nations' in the land of Canaan (Deut. 7:1; cf. Josh. 3:10; 24:11), the list of musical instruments at the sound of which Nebuchadnezzar's subjects are to fall in worship (Dan. 3:5, 7), and (following the climactic $\mathrm{x} / \mathrm{x}+1$ formula) the 'seven things' that Yahweh detests (Prov. 6:16-19).

Another form of heptadic patterning which has been observed, more challenging to the reader (a point to which we will return), is the use of a key theme word or phrase in a given pericope or coherent block of text seven times or a multiple of seven times. Wenham, for example, draws attention to the occurrence of a number of key words or phrases seven times or a multiple of seven times in the opening chapter of the Bible (Gen. 1:1-2:3), such as 'God', 'earth', 'and it was so', 'and God

2 See Robert Gordis, 'The Heptad as an Element of Biblical and Rabbinic Style', $J B L$ 62 (1943): 17-26; Arvid S. Kapelrud, 'The Number Seven in Ugaritic Texts', VT 18 (1968): 494-99; John J. Davis, Biblical Numerology (Grand Rapids: Baker Book House, 1968): 103-124; ISBE 3:559; є̌пta in TDNT 2:627-34, esp. 627-29; Thomas McComiskey, "The Seventy "Weeks" of Daniel against the Background of Ancient Near Eastern Literature', WTJ 47 (1985): 18-45, esp. 35-40.

3 Denka Markova, Linda Njoh, and Michael Lloyd, 'Benford's Law and the Bible', http://arapaho.nsuok.edu/ okar-maa/news/okarproceedings/OKAR-2006/bible.pdf (accessed 26 September 2011).

4 David A. Dorsey, The Literary Structure of the Old Testament: A Commentary on Genesis-Malachi (Grand Rapids: Baker Academic, 1999). 
made', and 'and God saw that it was good', in counterpoint to the seven-day literary framework of the pericope. ${ }^{5}$

In this article I propose to examine the block of text in 1 Kings 1-11 dealing with the reign of Solomon to consider its employment of sevenfold verbal patterns and in particular its sevenfold repetitions of a number of words and phrases which seem to be thematic for the particular pericope or the Solomon narrative as a whole. No claim is made regarding the privileging of the number seven as over against others such as three, ten or twelve which also seem to assume some prominence in the Hebrew Bible. As Benford's Law suggests, clusters of fewer than seven items will be expected to occur with higher frequency in the natural world. We cannot assume Benford's Law applies in a simplistic manner in literature as well. Threefold clusters, for example, as noted above, are a common literary phenomenon, creating a sense of satisfaction across a range of genres, and in narrative particularly, giving scope for progression and climax within an economical compass and could be expected, according to literary theory, to occur with even greater frequency than that found in the natural world. ${ }^{6}$ However, in view of the observation of others that the biblical writers employ heptadic patterns, it seems a worthwhile enterprise to endeavour to uncover the possible working into the Solomon narrative of patterns utilising sevenfold iterations and to reflect on their possible significance. Further impetus to this enquiry is given by the recognition of the heptadic symbolism of the temple construction and dedication, a building taking seven years to complete (1 Kings 6:38), being dedicated in the seventh month (1 Kings 8:2) at a festival lasting seven (LXX) or fourteen (MT) days (1 Kings 8:65) and of course Solomon himself rounds off his achievements by marrying seven hundred royal wives as well as three hundred concubines (1 Kings 11:3).

While some of the patterning observed below has been noted previously, a number of the examples discussed are (to my knowledge) fresh, and I am not aware of any study that has endeavoured to bring

5 Gordon Wenham, Genesis 1-15 (Word Biblical Commentary; Waco, TX: Word Books, 1987): 6 .

6 According to Benford's law, clusters of three should represent $12.5 \%$ of natural groupings of one to nine items. The 'Rule of Three' suggests it will be higher in literary groupings. 
together such observations and consider their possible literary effect as a whole.

There is inevitably a certain amount of subjectivity in such a process. Can we be certain that we have defined the limits of a pericope or larger body of text, i.e. does it have formal and thematic coherence determined on other criteria? Have we identified genuinely key words or are we simply counting any word that happens to occur seven times in a given pericope (it is statistically inevitable in a given range that some words will occur seven times)? Should we count only identical lexical forms (lemmas), or roots? However, in most if not all of the cases discussed below, there would be substantial agreement on delimitation issues, and many of the examples would remain valid whether lexical forms or roots are used. I have left out of consideration some observed sevenfold repetitions of words on the grounds that they are very common words or roots (דבר ,קום , שוב). I leave it to the reader to discern whether the words considered are central or peripheral to the passages under discussion as there does not seem to be an objective way of demonstrating this.

\title{
2. Sevenfold Lists
}

Lists of persons or items of varying lengths are to be found in the Solomon narrative (1 Kings 1-11). If we count only those lists of between three and nine items (it seems difficult to define anything less than three as a list), we can produce something like the following tabulation:

\author{
lists of three: twenty-seven instances \\ lists of four: six instances \\ lists of five: six instances \\ lists of six: one instance \\ lists of seven: four instances ${ }^{7}$ \\ lists of eight: one instance \\ lists of nine: one instance.
}

\footnotetext{
7 I have not counted 1 Kings 4:23 (Heb. 5:3) where we have a list of the seven meats available on Solomon's menu: fattened cattle, grazing cattle, sheep, deer, gazelles, roe deer, and fattened poultry as these arguably form part of a longer list of food items beginning with 4:22 (Heb. 5:2), or the itemisation of Solomon's expertise in the study of flora and fauna (1 Kings 4:33 [Heb. 5:13]) where some items are subcategories of others.
} 
We thus observe a generally diminishing scale, with a heavy weighting towards threefold lists (as the 'Rule of Three' might suggest) and with the sevenfold lists also being something of an aberration from a simple logarithmic progression.

These sevenfold lists are as follows:

1. At 1 Kings 2:3 we have a sevenfold accumulation of expressions for Solomon's covenantal responsibility: charge, ways, statutes, commandments, ordinances, testimonies, law.

2. Then there is the sevenfold catalogue of disasters that will befall unfaithful Israel: famine, plague, blight, mildew, locust, caterpillar, besieging enemy (1 Kings 8:37).

3. At 1 Kings 10:4-5 we have an itemisation of the evidence of Solomon's wisdom as observed by the Queen of Sheba in the following list: the house that he built, the food of his table, the organisation of his officials, the service of his attendants, their clothing, his cupbearers, and the burnt offerings he offered at Yahweh's house.

4. Finally the tribute of the nations flows to Solomon in the following sevenfold form: silver, gold, garments, weapons, spices, horses, and mules (1 Kings 10:25).

We thus have a reminder of Solomon's covenant obligations at the beginning of his reign and before his building ventures, and a matching set of solemn warnings of impending judgement on unfaithfulness following their completion. The Queen of Sheba's summary of Solomon's grandeur, measured in material wealth, is both an indication of blessing at one level and a hint that Solomon's priorities may have been skewed (the initial reference to the 'house' that the Queen admired is best understood as Solomon's palace, with the sacrifices at Yahweh's 'house' being left to the end of the list). Finally the items brought by visitors to Jerusalem may on the surface appear to enhance Solomon's grandeur as he receives the tribute of the nations, yet these are framed so as subtly to depict him as having fallen foul of the criteria by which Israel's kings are to be judged (Deut. 17:14-20) and thus prepare the reader for the judgement that befalls the monarchy.

\section{Sevenfold Verbal Repetitions}

We turn now to a consideration of those words and phrases that seem to be key to the thematic purpose of the author that are repeated seven 
times or a multiple of seven times in either a shorter pericope or the whole Solomon narrative.

Chapter 8 is a good place to begin as it clearly forms a coherent unit of 1 Kings, recounting the dedication of the temple. A number of heptadic verbal repetitions are to be noted in intricate interaction throughout the chapter.

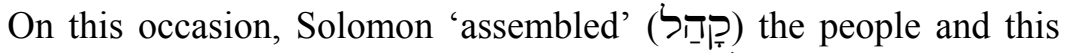
word, either as a verb, or the corresponding noun קָָָר 'assembly', is to be found seven times throughout the chapter (1 Kings 8:1, 2, 14 [2×], $22,55,65)$. The point of a temple is not its splendid architecture or lavish furnishings, but the presence of God among his assembled people as at Mount Sinai, the original 'assembly' of the covenant community (Deut. 4:10).

The setting of the chapter and its main subject matter is the temple with its envisaged role in the future of God's people. The word 'house'

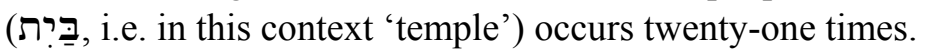

The point of the temple is Yahweh's association with it. Kings reflects the Deuteronomic preference for speaking of this association by referring to God's 'name' in relation to the election of a place for his worship. The temple is built 'for the name' of Yahweh. The celebration of Yahweh's association with the temple in 1 Kings 8 mentions his 'name' fourteen times (1 Kings 8:16, 17, 18, 19, 20, 29, $33,35,41,42,43[2 \times], 44,48)$.

The temple, as envisaged in 1 Kings 8 , is the focal point for prayer, most notably as Israel finds itself in the future in exile and needing to repent and entreat God's mercy. The word 'prayer' is found seven times in the chapter (1 Kings 8:28 [2x], 29, 38, 45, 49, 54) for the appeal to God's covenant faithfulness and mercy.

Solomon's prayer, central to the chapter, is structured in seven petitions (8:31-53), where each petition follows the formula: 'When a particular scenario transpires involving sin and its consequences, and when people pray towards your temple, then hear from heaven and act.' The central petition (often the focal point in Hebrew rhetorical patterning $)^{8}$ contains the sevenfold list of covenant curses mentioned above (v. 37).

The prayer contains seven references to 'sin', but (as with the patterning in Genesis 1 noted above), these are in counterpoint with the

8 Cf. Dorsey, Literary Structure, 39-41. 
seven petitions $(8: 31,33,35[2 \times], 46,47,50)$, so not an inevitable outcome of the structure. The point of the prayer is to entreat God's mercy and there are seven occurrences of the word 'plea (for mercy)' in the prayer, also in counterpoint with the structure of the prayer $(8: 28$, $30,38,45,49,52[2 \times])$. Besides the formulaic 'hear in heaven' which serves to define the sevenfold petitional pattern, there are a further seven instances of 'hear' within the prayer $(8: 28,29,30$ [3×], 42, 52). The word 'people' (those on whose behalf the prayer is offered) occurs fourteen times within the prayer $(8: 30,33,34,36$ [2× ], 38, 41, 43 [2×], $44,50,51,52,53)$.

Elsewhere within the Solomon narrative, there are further instances of sevenfold patterning. The narrative of 1 Kings 1-2 concerns the succession within the dynasty or 'house' of David. The word 'house' in this sense is found in 1 Kings 2:24, 33, but the opening chapters play with the word in other senses - the 'homes' of Adonijah, Joab, and Shimei; the 'family' of Eli (1 Kings 1:53; 2:24, 27, 31, 33, 34,36 ) - seven references in all. Just as they point back to the house that Yahweh promised to build for David (2 Sam. 7:11), they anticipate the concern with the construction of Yahweh's house that occupies the central chapters of the Solomon narrative.

The question of the succession is voiced seven times with the expression 'sit on the throne' in 1 Kings 1 . Note the chiastic pattern of the sequence of subjects and noun phrases after the preposition:

A. Solomon ... on my throne (v. 13)

B. Solomon ... on my throne (v. 17)

C. Who? ... on the throne of my lord the king (v. 20)

D. Adonijah!? ... on my throne (v. 24)

$\mathrm{C}^{\prime}$. Who? ... on the throne of my lord the king (v. 27)

$\mathrm{B}^{\prime}$. Solomon ... on my throne (v. 30)

$\mathrm{A}^{\prime}$. Solomon ... on my throne (v. 35)

Adonijah, who has made the pre-emptive move regarding the succession, is the central figure of the pattern, but Nathan's attribution to David of the assertion (v. 24) that it would be Adonijah who would sit on the throne is ironic ('You have apparently said ...', or in the form of a question ('Have you said ...?'). This is bracketed by the two repetitions of the formula with interrogative pronoun subject: 'Who ...?' and outflanked by the fourfold assertion of Solomon's claim to the throne. 
The root שבעע 'pledge, oath, swear' occurs seven times in the account of Solomon's rivalry with Adonijah and accession to the throne (1 Kings 1:13, 17, 29, 30; 2:8, 23, 42) which revolves around pledges given or alleged to have been given and hollow pledges effectively nullified. Is Solomon's claim to legitimacy based on a fabrication (by Nathan and Bathsheba) and shored up by his complicity in a breach of faith in the case of Shimei?

The short pericope of 1 Kings 3:16-28 turns on the rival accounts of two women and their claim to be the mother of a living child. The word 'woman' occurs seven times (1 Kings 3:16, 17 [2×], 18, 19, 22, 26) while the root ילד also occurs seven times in various forms, serving to bind the passage together: as the verb 'give birth' in qal finite and infinitive forms ( 1 Kings $3: 17,18[2 \times], 21)$; as the noun 'child' (1 Kings 3:25); and as the qal passive participle 'bairn, child' (1 Kings $3: 26,27)$.

Solomon is presented as the paragon of wisdom. The pericope that offers a summary encomium on this wisdom is 4:29-34 (Heb. 5:9-14) which makes sevenfold use of the root ('be wise, wisdom' as verb and noun) to underscore its point $(4: 29,30[3 \times], 31,34[2 \times]$ [Heb. 5:9, $10[3 \times], 11,14[2 \times])$.

So far our observations have focussed on word repetitions within shorter pericopes. Is it possible that author and reader could extend their literary appreciation of such patterning to longer units of text?

The word שָׁלו 'peace, well-being' echoing Solomon's name, occurs seven times in connection with Solomon in 1 Kings 1-11 (2:5, 6, 13 [2×], 33; 4:24 [Heb. 5:4], 5:12 [Heb. 5:26]). The point may be subtler than commonly supposed and we are given sufficient cause to question the character of the 'peace' associated with Solomon's reign when several of the contexts relate to violence and treachery. The writer may want us to read between the lines when it comes to the general well-being Solomon presided over.

Closely related is the negative side of the security of the Solomonic reign. Solomon makes a number of 'blows' (פגע) to consolidate his power as he strikes down in turn Adonijah, Joab, and Shimei (1 Kings $2: 25,29,31,32,34,46)$. As a consequence, in the seventh, and only other use of the root in Kings, Solomon himself is said to be enjoying

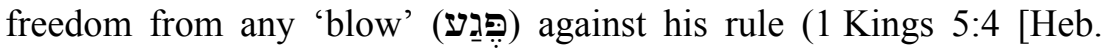
$5: 18]$ ). We may wonder how long such freedom from any opponent or misfortune may last if it is based (at least in part) on questionable pre- 
emptive strikes and we may detect a measure of irony when we are later told that Solomon did have an adversary all through his reign (1 Kings 11:25).

The word 'good' is a theme word for the Davidic covenant blessing (2 Sam. 7:28), ${ }^{9}$ and behind that, as noted above, characterises the created order. In this sense, there are seven occurrences of this word in the Solomon narrative (1 Kings 3:9; 8:18, 36, 56, 66 [2×]; 10:7), where it is used to link Solomon's and his people's expected covenant response with the prospect of divine blessing.

We have already noted the seven instances of the root חכם 'be wise, wisdom' in the pericope 4:29-34 (Heb. 5:9-14). There are a further fourteen instances of this root in the whole of the Solomon narrative. Beginning with David's appeal to Solomon to exercise his 'wisdom' in the murder of Joab (1 Kings 2:6) and ending in the summary of his reign (1 Kings 11:41), there are thus twenty-one occurrences of the root חכ in association with Solomon and his building enterprise. ${ }^{10}$ Again, the writer may wish to keep this concept to the fore so that we will ponder the character of Solomon's wisdom. Does he exercise wisdom for the good of Israel or his own aggrandisement?

The question of Solomon's commitment to God's covenant is never far from the forefront of the writer's concern. There are seven references in all in the Solomon narrative to the 'covenant' (1 Kings $3: 15 ; 6: 19 ; 8: 1,6,21,23 ; 11: 11)$. While all but the final two refer to the ark and its documentary covenant deposit, a constant reminder to king and people of God's commitment and a challenge to their own covenant response, the last two make explicit God's faithfulness and finally Solomon's covenant failure.

Much of the Solomon narrative concerns his construction of the temple and associated buildings. We form the impression that the temple is not Solomon's top priority and that, from the writer's perspective, its completion is unduly delayed. Seven times we are informed that Solomon 'finished' various phases of the construction work (כִִּ 1 Kings $6: 9,14,38 ; 7: 1,40 ; 8: 54 ; 9: 1$ ). While the first three and last three occurrences refer in some way to the temple and its

\footnotetext{
9 Walter Brueggemann, 'The Kerygma of the Deuteronomistic Historian', Interpretation 22 (1968): 387-402, esp. 401-402.

10 Cf. L. Kalugila, The Wise King: Studies in Royal Wisdom as Divine Revelation in the Old Testament and Its Environment (Coniectanea Biblica Old Testament Series 15; Lund: Gleerup, 1980): 107.
} 
furnishings, the central reference (1 Kings 7:1) is to Solomon's own house. Is it the palace rather than Yahweh's temple that is central to Solomon's concerns?

The reign of Solomon was Israel's golden age. This is reinforced with twenty-eight references to 'gold' in connection with Solomon's reign throughout 1 Kings $1-11$. The gold, streaming to Jerusalem from Solomon's trading ventures and tribute, decorates the temple and Solomon's other showcase buildings. Through his repeated use of this key word the writer wants us to have a clear impression of this opulence partly because he will subtly suggest that this is in contravention of the law of the king in Deuteronomy 17:15-20 (the accumulation of breaches of this law in 1 Kings 10:26-11:2 seems unmistakable) and partly because he will want us to follow the decline of Israel's fortunes as measured by the loss of this gold through the rest of 1-2 Kings.

The nation of Egypt looms large in the Solomon narrative. The constant subtle comparisons drawn between Israel under Solomon and the country of Israel's bondage are not flattering to the one whose temple construction should ideally mark the culmination of the deliverance from that bondage (1 Kings 6:1). Mention of Solomon's marriage to Pharaoh's daughter forms an inclusio around the account of his reign (1 Kings $3: 1 ; 11: 1)$ and the forced labour Solomon imposes on his own people (1 Kings 5:13-14 [Heb. 5:27-28]) has a disturbingly Pharaonic ring to it. ${ }^{11}$ Egypt is mentioned a total of fourteen times (1 Kings 3:1; 4:21 [Heb. 5:1], 30 [Heb. 5:10]; 6:1; 8:9, 16, 21, 51, 53, $65 ; 9: 9,16 ; 10: 28,29)$.

\section{General Observations}

What are we to make of such observations? Some of the patterns observed above may be simply the result of statistical inevitability. We can of course find words with other frequencies of occurrence, e.g. to take chapter eight, we could say that the word 'priest' occurs five times, or the word 'ark' nine times. It would take a study far beyond

11 See Amos Frisch, 'The Exodus Motif in 1 Kings 1-14', JSOT 87 (2000): 3-21; M. D. Oblath, 'Of Pharaohs and Kings - Whence the Exodus?', JSOT 87 (2000): 2342; John W. Olley, 'Pharaoh's Daughter, Solomon's Palace, and the Temple: Another Look at the Structure of 1 Kings 1-11', JSOT 27 (2003): 355-69. 
the scope of this to analyse the frequency of every word. I am not, therefore, making a claim that every heptadic pattern is intentional. However, we ought not to rule out the possibility of a compositional strategy to work in both heptadic lists and a heptadic pattern of repetitions of key words and phrases through smaller pericopes and larger blocks of text. This would suggest a careful process of writing and/or editing.

How could an ancient reader or hearer of the recited text be expected to observe and appreciate such patterns, we wonder? Dorsey raises and addresses the question with reference to the discernment of structural elements (some of which span large units of text) observing that in order to be valid the elements would need to be discernible at least on the 'first few readings' rather than necessarily on a single reading. ${ }^{12}$ Since (by comparing the MT with the Qumran biblical texts and LXX in particular) we are able to observe something of the process of the editorial shaping of the text in the late Second Temple period within the era of scribal schools, ${ }^{13}$ perhaps we may also posit that some of the patterns have been carefully worked in by a thoughtful editor anticipating the study and appreciation of the written text rather than simply its oral reading. The attentive student would then be able to verify his impressions by a perusal or close study of the scroll. We observe something of a scribal trend in this direction, for example, in the tendency of the LXX (or its Vorlage) to prefer a higher incidence of seven-nation lists of the original occupants of the land. ${ }^{14}$ We may be inclined to rule out as intentional those patterns that would be more difficult to discern (those involving multiples of seven, or repetitions within larger blocks of text) because not every reader could be expected to recognise all or even any of the patterns. Yet it is a mark of good writing that it may be appreciated by a variety of readers at different levels, and we do not disregard other literary devices (chiasmus, inclusio, paronomasia, acrostic) because not every reader will readily identify them. It is by no means suggested that one needs to recognise the numeric patterns in order to understand the overall message and appreciate other dimensions of the writing. Some of the

12 Dorsey, Literary Structure, 35.

13 Karel van der Toorn, Scribal Culture and the Making of the Hebrew Bible (Harvard: Harvard University Press, 2007).

14 See Tomoo Ishida, 'The Structure and Historical Implications of the Lists of PreIsraelite Nations', Biblica 60 (1979): 461-90. 
patterning, particularly the lists and the repetitions of words within a short pericope, may be subconsciously produced and recognised (a perception of three instances either side of a central one does not require a conscious count).

What, then, might be contributed by the employment of heptadic patterns in the Solomon account? It is not proposed to invest any of the instances with some mystical 'Bible Code' significance, i.e. an esoteric meaning inaccessible to the naïve reader. The astute reader does not find in the text a substantially different significance from the relatively unsophisticated reader, but the readerly experience is enhanced through the appreciation of literary techniques which may reinforce and enhance other aspects of the text. Van der Toorn discusses the culture of scribes producing texts with other scribes in view as their readers. ${ }^{15}$ In part the literary effect of sevenfold lists and repetitions may be simply that of underscoring the notion of completeness. There would be a sense of satisfaction and a resultant perception of cohesion for a textual unit, as for example with the sevenfold chiasm in 1 Kings 1 regarding who is to sit on David's throne, or the woman/child pattern of 3:16-28.

It may also be the case that in Israel the number seven will sometimes have creational/re-creational overtones related to the tradition of a creation week preserved in Genesis 1-2 (and Exod. 20:11) which ends with a sabbath rest of fulfilment. Solomon's temple is a microcosm of the ideal or restored creation. ${ }^{16}$ It could be then that the heptadic structure and patterning in chapter 8 serve in part to reinforce this symbolism of the temple dedication as a prototypical new creation event. The focus on 'heaven' in 1 Kings 8 may recall the thematic role this word has in Genesis 1-2 (and other creational passages) as the counterpart to 'earth' and point us forward, through the cosmic symbolism inherent in the temple, to the restoration and renewal of the universe (cf. Isa. 65:17; 66:22).

15 Van der Toorn, Scribal Culture, 40, 116.

16 J. D. Levenson, Creation and the Persistence of Evil: The Drama of Divine Omnipotence (San Francisco: Harper and Row, 1988): 78-99; E. Bloch-Smith, 'Who Is the King of Glory? Solomon's Temple and Its Symbolism', in Scripture and Other Artifacts: Essays in Bible and Archaeology in Honor of Philip J. King, ed. M. Coogan et al. (Louisville: Westminster John Knox Press, 1995): 18-31; G. K. Beale, The Temple and the Church's Mission: A Biblical Theology of the Dwelling Place of God (New Studies in Biblical Theology; Downers Grove: IVP, 2004): 29-80. 
Solomon's 'gold', the symbol of opulence adorning the temple and his private residence, may call to mind the first reference to it in the primary history, the 'gold' that lay in the ground (Gen. 2:11-12) awaiting creative use. Is the temple, for all its gold, the ultimate realisation of a creational ideal or can this gold be put to even better use?

The sevenfold use of the word 'finish' (culminating in the microcosm of the temple) may call to mind the use of the same word for God's completion of his larger scale creative enterprise (Gen. 2:1), so reinforcing the creational connection of the temple.

The word 'sin, offence' is not found in the creation account of Genesis 1-3, but is found in Israel's theological vocabulary (e.g. Ezek. $28: 16$, a text roughly contemporary with an exilic dating of Kings) to describe the cause of the expulsion of the primal man from the 'mountain of God'. It is the dire possibility of a re-enactment of this expulsion from the new mountain of God, the land of Israel, that is in view in its sevenfold repetition in 1 Kings 8 .

Solomon's rule should ideally represent the climax of the exodus, the return to the mountain of God, a restoration of the divine image and the renewal of the world order with God at the centre. Solomon is set up to be the promised royal seed of Genesis 3:15 par excellence. He sits on a seven-tiered throne dais (six steps plus the throne level: 1 Kings 10:18-20) which is perhaps to be understood as containing creation symbolism (six creation days followed by the seventh of rest and fulfilment). We may be justified then in seeing creational implications in some of the heptadic patterns not only in close connection with the temple but more generally with Solomon's kingship. ${ }^{17}$ This section is not intended to be exhaustive but suggestive.

The word 'peace, well-being' is used elsewhere with creational and re-creational associations (Lev. 26:6; Isa. 45:7; 55:12; Ezek. 37:26). While we cannot be certain that the writer of Kings was familiar with these traditions (though again the prophetic texts are generally regarded as near contemporary), we may be given cause to ponder whether Solomon's reign of peace is truly the restoration of an Edenic ideal or

17 Elsewhere I have argued on other grounds that Solomon is portrayed in $1 \mathrm{Kgs} 1-11$ as a new Adam figure: John A. Davies, "Discerning between Good and Evil": Solomon as a New Adam in 1 Kings', WTJ 73 (2011): 39-58; cf. G. K. Beale, A New Testament Biblical Theology: The Unfolding of the Old Testament in the New (Grand Rapids, Baker Academic, 2011): ch. 2. 
whether we should look beyond Solomon's imperfect expression of peace to a more hopeful future. ${ }^{18}$ Likewise the repetitions of the word 'good' in association with the relationship between God and his world, centred on his king, echo the heptadic use of 'good' at the beginning of the primary history (Genesis 1) and may point us beyond the immediate apostasy we observe with Solomon to a hope of a restoration of creational blessing through a Davidic king.

The repetition of the word 'name' may recall the naming (dominion) role given to Adam over every living creature (Gen. 2:19-20). Solomon enjoys a dominion unrivalled by any other king of Israel both in its geographical extent (1 Kings 4:21 [Heb. 5:1]), and in his mastery of the created order (1 Kings 4:33 [Heb. 5:13]).

Solomon's wisdom is an attribute of deity exercised in the creation (Prov. 3:19) and one presumed in Israel's creation tradition (as articulated in the exilic period) to have been possessed by the primal man (Ezek. 28:12). The sevenfold iteration of terms for the covenant obedience expected of the king in 1 Kings 2:3 recalls the unquestioning obedience required of Adam and Eve. It is particularly the central word 'command' that echoes the 'command' of God not to eat from the forbidden tree (Gen. 2:16; 3:11, 17).

The evidence is thus suggestive of a schematised pattern of verbal usage in the Solomon narrative with both a general purpose of highlighting certain key concepts and enhancing the general sense of completeness, while also subtly encouraging the reader to draw comparisons between Solomon in his domain and Adam in his, and perhaps to look beyond to 'one greater than Solomon' (Matt. 12:42).

18 For the idea that Kings conveys a message of hope, see Brueggemann, 'Kerygma'. 